\title{
Invasive Lobular Breast Carcinoma, Alveolar Variant
}

National Cancer Institute

\section{Source}

National Cancer Institute. Invasive Lobular Breast Carcinoma, Alveolar Variant. NCI

Thesaurus. Code C97049.

A grade I invasive lobular carcinoma of the breast, characterized by the presence of round groups of neoplastic cells. 